* Department of Veterinary Pathobiology,

$\uparrow$ Department of Microbiology, College of Biological Sciences, $\ddagger$ and Comprehensive Cancer Center,

The Ohio State University,

1925 Coffey Road,

Columbus, Ohio 43210

Received 24 April; accepted 26 June 1978.

1. Anderson, L. J., Jarrett, W. F., Jarrett, O. \& Laird, M. J. natn. Cancer Inst. 47, 807-817 (1971)

2. Cockerell, G. L., Hoover, E. A., Krakowka, S., Olsen, R. G. \& Yohn, D. S. J. natn. Cancer Inst. 57, 1095-1099 (1976)

3. Essex, M. Adv. Cancer Res. 21, 175-248 (1975).

4. Hoover, E. A., Perryman, L. E. \& Kociba, G. L. Cancer Res. 33, 145-152 (1973).

5. Perryman, L. E., Hoover, E. A. \& Yohn, D. S. J. natn. Cancer Inst. 49, 1357-1365 (1972).

6. Dent, P. B. Progr. med. Virol, 14, 1-35 (1972).

7. Jarrett, W. F. Crawford, E. M. Martin, W. B. \& Davis, F. Nature 202, 567-568 (1964)

8. Hoover, E. A. Krakowka, S., Cockerell, G. L., Mathes, L. E. \& Otsen, R. G. Am. J. vet. Res. 39, 993-995 (1978).

Cockerell, G. L. \& Hoover, E. A. Cancer Res. 37, 3985-3989 (1977).

10. Hebebrand, L. C., Mathes, L. E. \& Olsen, R. G. Cancer Res. 37, $4532-4533$ (1977).

11. Fowler, A. K., Twardzik, D. R., Weislow, O. S. \& Hellman, A. Cancer Res. (in the press).

12. Cooperband, S. R., Glasgow, A. H. \& Mannick, S. A. in Immune Depression and Cancer (ed. Siskind, G. W., Christian, C. L. \& Litwin, S. D.) 135-190 (Grune and Stratton, New York, 1975).

13. Brandchaft, P. B., Aoki, T. \& Silverman, T. N. Int. J. Cancer 17, 678-685 (1976).

14. Dorio, A. M., Barzi, A., Morietti, P. R., Goldin, A. \& Bonmassar, E. Cancer Res. 36, 3851-3853 (1976)

15. Wood, G. W. Cancer Res. 36, 4552-4557 (1976)

16. Olsen, R. G., Hoover, E. A., Schaller, J. P., Mathes, L. E. \& Wolff. L. H. Cancer Res. 37, 2082-2085 (1977).

17. Schaller, J. P., Hoover, E. A. \& Olsen, R. G. J. natn. Cancer Inst. 59, 1441-1450 (1977). 18. Levine, A. S. \& Ginsberg, H. S. J. Virol. 2, $430-439$ (1968).

19. Mathes, L. E., Yohn, D. S. \& Olsen, R. G. J. clin. Microbiol. S, 372-374 (1977).

20. Cockerell, G. L., Hoover, E. A. \& LoBuglio, A. F. Am. J. vet. Res. 36, 1489-1494 (1975).

\section{Fusion of Sendai virus with the target cell membrane is required for $\mathbf{T}$ cell cytotoxicity}

INFECTION of mice with viruses can generate cytotoxic $T$ lymphocytes (CTL) which show restricted specificity for target cell lysis. Specific lysis requires that the virus used to prime the target cells must be of the same type as that used to sensitise the CTL, and that both target and CTL cells must express the same major histocompatability complex (MHC) gene product(s). The nature of the viral gene product(s) and their interaction with the MHC gene product(s) have been the subject of recent study ${ }^{1-5}$. Previously we used Sendai virus to show that lysable target cells can be obtained using membrane vesicles which contain only the viral glycoproteins, indicating that these may be the specific viral gene products involved in target formation ${ }^{5}$. Sendai virus contains two glycoproteins-the haemagglutinin-neuraminidase (HANA) which promotes attachment of virus to cells and the fusion protein $(F)$ which is involved in subsequent virus cell fusion ${ }^{7-9}$. Both activities are necessary for insertion of these viral glycoproteins into the plasma membrane of the cell ${ }^{10}$. In this letter we suggest that the insertion of the viral glycoproteins into the cell membrane is an essential step in target cell formation since we can show that virus containing an inactive fusion protein precursor $\left(F_{0}\right)$ cannot elicit $T$ cell cytotoxicity unless the fusion activity is generated by proteolytic cleavage of the precursor. Sugamura et $a l .^{6}$ have suggested that it is primarily the $F$ glycoprotein of the Sendai virus envelope which is essential for the formation of the target antigen, as virus lacking the functional activities of F following trypsin digestion was inactive in priming target cells for $T$ cell killing. However, we show that proteolytic inactivation of either of the two glycoproteins (F or HANA) of virus used to prime target cells will abolish the cytotoxic response.

Virus-specific effector cells bearing the surface markers Thy $1^{+}$, Ly $2^{+} 2^{+}$and $\mathrm{L}^{+}$(M. Horton et al., in preparation) were generated in vitro by secondary stimulation ${ }^{5}$ of in vivo primed mouse spleen cells with noninfectious ( $\beta$-pro-

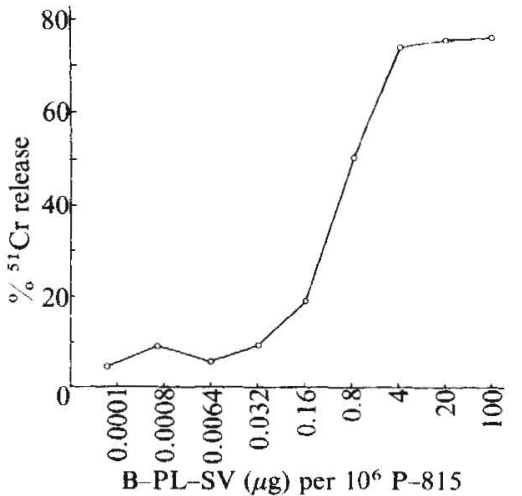

Fig. 1 Dilution curve for Sendai virus-specific T cell-mediated cytolysis. P-815 cells were incubated with $\beta$-propiolactonetreated Sendai virus for $1 \mathrm{~h}$ at $37^{\circ} \mathrm{C}$ and washed three times with medium. Susceptibility to Sendai virus specific CTLs was measured by the ${ }^{51} \mathrm{Cr}$ release assay described previously using $10^{4}$ target cells per well ${ }^{5}$. Results are from triplicate assays; s.d. were always less than 3. Spontaneous lysis was $12 \%$ and has been subtracted. $\mathrm{O}$, Lysis of ${ }^{51} \mathrm{Cr}$ labelled P-815-Sendai virus treated cells; , lysis of untreated P-815 cells.

piolactone-inactivated) Sendai virus $(20 \mu \mathrm{g}$ virus protein per $10^{6}$ cells). In experiments designed to calibrate the cytotoxic assay, the degree of lysis was shown (Fig. 1a) to be related to virus concentration over the range $0.16-4 \mu \mathrm{g}$ of virus protein using $10^{6} \mathrm{P}-815$ target cells, corresponding to approximately $10^{4}-10^{5}$ virus particles per cell. Amounts of virus greater than $4 \mu \mathrm{g}$ did not increase the degree of lysis. Thus investigations of changes in target formation by different virus preparations must be carried out in a concentration range which gives a linear response in the assay.

In the experiment described above and in previous work ${ }^{5}$ we have used egg-grown Sendai virus which is active in fusion. To investigate further the role of virus-cell fusion in target cell formation we purified Sendai virus produced in MDBK cells. This virus contains $F_{0}$ and is inactive in fusion and noninfectious although it contains an active HANA glycoprotein and can attach to the cell surface ${ }^{9}$. Activation of fusion requires proteolytic cleavage of the $F_{0}$. When Sendai virus is grown in embryonated eggs this cleavage presumably occurs at the plasma membrane. In MDBK cells this cleavage does not occur but MDBK grown virus can be cleaved in vitro by low concentrations of trypsin with restoration of the fusion and haemolytic activities and also of infectivity ${ }^{9}$. In Table 1 the haemagglutinin, neuraminidase, haemolytic and target formation activities of trypsin treated MDBK-Sendai are compared with those of untreated MDBK-Sendai and egg-grown Sendai virus. MDBK-Sendai does not cause significant cell-mediated cytolysis $(\mathrm{CMC})$ unless it is activated by pretreatment with trypsin. The small amount of target formation obtained with MDBK-Sendai is probably due to the small proportion of cleaved $F$ which is always found in these virus preparations. These results suggest that MDBK-Sendai virus will not form lysable target cells because the virus and hence the viral glycoproteins cannot fuse with the cell membrane. To show that the glycoproteins of virus containing $F_{0}$ can function in target formation if they are present in the cell membrane, P-815 cells were infected with a low dose (10 EID per cell) of live egggrown Sendai virus. This input of virus is too low to cause immediate target cell formation but after incubation for $24 \mathrm{~h}$ at a time when virus containing $F_{0}$ and HANA was being released from the P-815 cells (results not shown) the target cells were specifically lysable. However, P-815 cells treated with P-815 grown Sendai virus were not lysed by T-killer cells unless the virus was activated by pretreatment with trypsin to convert $F_{0}$ to $\mathrm{F}$ (Table 1). These results further support the hypothesis that the process of fusion and membrane insertion of viral glyco- 
proteins is a major requirement for target formation, as virus containing $F_{0}$ can form targets if the viral glycoproteins are inserted in the cell membrane from within the cell.

Although these results suggest that $\mathrm{T}$ cell-mediated cytolysis requires the presence of viral antigens in the plasma membrane it is possible that the $T$ cells might recognise viral antigens that are bound to but not fused into the cell surface. In order to try to distinguish a recognition phase from a killing phase we have used unlabelled target cells having viral antigens either fused into the membrane or merely attached to the cell surface to compete with ${ }^{51} \mathrm{Cr}$ labelled Sendai-treated target cells for lysis by $T$ killer cells. The results shown in Fig. 2 indicate that cells coated with MDBK-Sendai virus do not compete for lysis of labelled targets to a greater extent than do normal cells at the same density. In contrast, target cells treated with trypsinised MDBK-Sendai virus or with egg-grown Sendai virus will compete effectively. Thus attachment of virus to target cells is insufficient for T-cell recognition as well as for $\mathrm{CMC}$.

To investigate further the involvement of the Sendai virus glycoproteins in target formation we used limited proteolytic digestion of $\beta$-propiolactone-treated virus to selectively inactivate the $F$ or HANA glycoproteins. The effect of the protease treatments on the viral activities is shown in Table 2. Digestion of virus with pronase or the V8 protease of Staphyloccus aureus eliminates the haemagglutinin and neuraminidase activities, while treatment with trypsin (a concentration higher than that required for precursor cleavage) causes only a small decrease in these activities. All enzymes abolish the fusion and haemolysis activities of the virus. Loss of HA activity prevents attachment of virus to cells and thus prevents the subsequent virus-cell fusion even if the fusion protein is active. Using polyacrylamide gel analysis we have shown that pronase cleaves both $F$ and HANA while trypsin cleaves $F$ and the $\mathrm{V} 8$ protease removes the HANA. The fusion protein of virus treated with V8 protease is indistinguishable from that of untreated virus by analysis on polyacrylamide gels, immunological analysis and amino acid composition (M.-J. G. and M. W., in preparation). Target formation by the protease treated virus preparations was evaluated after incubation of $10^{6} \mathrm{P}-815$ cells with modified or untreated virus. The results shown in Table 2 indicate that inactivation of not only $F$ but also HANA abolishes the capacity of virus to form target cells or reduces it by more than $99 \%$.

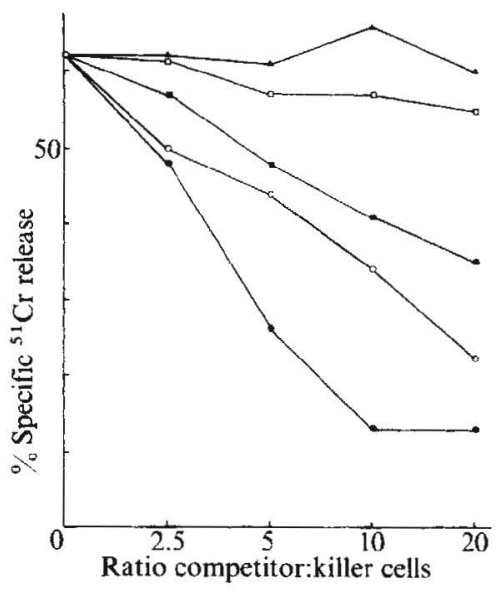

Fig. 2 Inhibition of $\mathrm{T}$ cell-mediated cytolysis of Sendai virustreated ${ }^{51} \mathrm{Cr}$-labeiled $\mathrm{P}-815$ cells by competitor P-815 cells treated with various Sendai virus preparations. Competitor cells: $\Delta$, P-815 control; $\square$, P-815 + MDBK-Sendai virus $\left(100 \mu \mathrm{g}\right.$ per $10^{6}$ cells);,$\quad \mathrm{P}-815+$ trypsin treated MDBK-Sendai virus $\left(100 \mu \mathrm{g} / 10^{6}\right.$ cells $) ; O, P-815+$ egg Sendai $\left(10 \mu \mathrm{g}\right.$ per $10^{6}$ cells $)$; , P-815 + egg Sendai $\left(100 \mu \mathrm{g}\right.$ per $10^{6}$ cells $)$. The cytotoxic test was carried out as described in Fig. 1. Killer: target cell ratio $10: 1$.

The results presented here show that the capacity of Sendai virus to fuse with a target cell is essential for $\mathrm{T}$-cell cytotoxicity. This process of fusion results in both the insertion of the viral glycoproteins into the cell membrane and also of the viral capsid into the cell. We previously reported that noninfectious Sendai virus (inactivated by UV light or $\beta$-propiolactone treatment) or artificial vesicles containing only the two glycoproteins were efficient in target cell formation ${ }^{5}$. We therefore suggest that the glycoproteins must be inserted into the cell membrane for target formation. We also show that inactivation of either of the two glycoproteins of Sendai virus will prevent target formation and this interference can be explained by a block at the level of virus-cell fusion. These results extend the observations of Sugamura et al. ${ }^{6}$. Such experiments cannot

Table 1 Effect of trypsin treatment on the glycoprotein activities of MDBK-Sendai virus

\begin{tabular}{|c|c|c|c|c|c|c|}
\hline \multirow{3}{*}{ Virus sample } & \multicolumn{3}{|c|}{ Cytotoxic assay } & \multirow{3}{*}{$\begin{array}{c}\text { Haemolysis } \\
\text { activity } \\
\left(A_{540} \text { per } 20 \mu \mathrm{g}\right)\end{array}$} & \multirow{3}{*}{$\begin{array}{l}\text { Haemagglutinin } \\
\text { activity } \\
\text { (HAU per } 20 \mu \mathrm{g} \text { ) }\end{array}$} & \multirow{3}{*}{$\begin{array}{c}\text { Neuraminidase } \\
\text { activity } \\
\left(A_{549} \text { per } 20 \mu \mathrm{g}\right)\end{array}$} \\
\hline & \multirow{2}{*}{$\mu \mathrm{g}$ virus } & \multicolumn{2}{|c|}{$\begin{array}{c}\%{ }^{51} \mathrm{Cr} \text { release } \\
\text { killer: target ratio }\end{array}$} & & & \\
\hline & & $20: 1$ & $5: 1$ & & & \\
\hline \multicolumn{7}{|l|}{ Expt 1} \\
\hline \multirow[t]{2}{*}{ Egg-grown Sendai virus } & 1 & 82 & 74 & 1.44 & 2,000 & 1.18 \\
\hline & 10 & 90 & 78 & & & \\
\hline MDBK-grown Sendai virus & $\begin{array}{r}10 \\
100\end{array}$ & $\begin{array}{r}5 \\
15\end{array}$ & $\begin{array}{r}2 \\
14\end{array}$ & 0.07 & 2,000 & 1.08 \\
\hline Trypsin treated MDBK-Sendai virus & 100 & 80 & 70 & 1.19 & 2,000 & 1.04 \\
\hline \multicolumn{7}{|l|}{ Expt 2} \\
\hline \multirow[t]{3}{*}{ Egg-grown Sendai virus } & 1 & 23 & 18 & 1.01 & 2,000 & 0.99 \\
\hline & 10 & 42 & 33 & & & \\
\hline & 100 & 49 & 35 & & & \\
\hline \multirow[t]{2}{*}{ P-815 grown Sendai virus } & 10 & 0 & 1 & 0.02 & 2,000 & 1.04 \\
\hline & 100 & 3 & 2 & & & \\
\hline \multirow[t]{2}{*}{ Trypsin treated P-815-Sendai virus } & 10 & 8 & 5 & 0.45 & 2,000 & 0.95 \\
\hline & 100 & 15 & 4 & & & \\
\hline
\end{tabular}

Purified $\beta$-propiolactone treated MDBK-Sendai virus or P-815-Sendai virus (1 mg in $2 \mathrm{ml}$ phosphate-buffered saline (PBS), $p \mathrm{H} 7.2)$ was incubated with trypsin $\left(2.5 \mu \mathrm{l}, 5 \mathrm{mg} \mathrm{ml}^{-1}\right.$ in $\left.1 \mathrm{mM} \mathrm{HCl}\right)$ for $10 \mathrm{~min}$ at $37^{\circ} \mathrm{C}$. The reaction was terminated by addition of soybean trypsin inhibitor $\left(10 \mu \mathrm{l}, 10 \mathrm{mg} \mathrm{ml}^{-1}\right.$ in PBS). Control samples of MDBK-Sendai virus and P-815-Sendai virus were treated in exactly the same manner except for the addition of trypsin. Haemagglutinin, neuraminidase and haemolytic activities were assayed as described previously ${ }^{5}$. The cytotoxic test was carried out as described in Fig. 1 legend. Spontaneous lysis from targets was $9-13 \%$. Release from noninfected targets was subtracted. The addition of soybean trypsin inhibitor had no effect on the cytotoxic assay. The cytotoxic assays in Expt 2 were carried out with a different batch of CTLs which were less active in cytolysis. 
Table 2 Effect of proteolytic digestion on activities of Sendai virus

\begin{tabular}{|c|c|c|c|c|c|c|c|c|}
\hline \multirow{5}{*}{$\begin{array}{l}\text { Protease } \\
\text { treatment }\end{array}$} & \multicolumn{3}{|c|}{ Cytotoxic assay } & \multirow{5}{*}{$\begin{array}{c}\text { Haemagglutinin } \\
\text { activity } \\
\text { (HAU per } \\
20 \mu \mathrm{g})\end{array}$} & \multirow{5}{*}{$\begin{array}{c}\text { Neuraminidase } \\
\text { activity } \\
\left(A_{549} \text { per } 20 \mu \mathrm{g}\right)\end{array}$} & \multirow{2}{*}{\multicolumn{2}{|c|}{ Fusion activity (per $20 \mu \mathrm{g}$ ) }} & \multirow{5}{*}{$\begin{array}{c}\text { Haemolysis } \\
\text { activity } \\
\left(A_{540} \text { per } 20 \mu \mathrm{g}\right.\end{array}$} \\
\hline & \multirow{4}{*}{$\mu g$ virus } & \multirow{2}{*}{\multicolumn{2}{|c|}{$\begin{array}{c}\%{ }^{51} \mathrm{Cr} \text { release } \\
\text { killer: target ratio }\end{array}$}} & & & & & \\
\hline & & & & & & \multirow{3}{*}{$\begin{array}{l}\text { Average no. } \\
\text { nuclei } \\
\text { per cell }\end{array}$} & \multirow{3}{*}{$\begin{array}{l}\% \text { of nuclei } \\
\text { in poly- } \\
\text { karyocytes }\end{array}$} & \\
\hline & & $20: 1$ & $5: 1$ & & & & & \\
\hline & & & & & & & & \\
\hline \multirow[t]{3}{*}{$a$, No enzyme } & 0 & 7 & 5 & & & & & \\
\hline & 1 & 86 & 58 & 2,048 & 1.01 & 5.2 & 94 & 1.86 \\
\hline & 10 & 90 & 62 & & & & & \\
\hline \multirow[t]{2}{*}{$b$, Trypsin } & 10 & 10 & 7 & & & & & \\
\hline & 100 & 7 & 2 & 2,048 & 0.94 & 0 & 0 & 0.02 \\
\hline \multirow[t]{2}{*}{$c, \mathrm{~V} 8$ protease } & 10 & 10 & 6 & & & & & \\
\hline & 100 & 30 & 12 & 32 & 0.03 & 0 & 0 & 0.01 \\
\hline \multirow[t]{2}{*}{$d$, Pronase } & 10 & 8 & 8 & & & & & \\
\hline & 100 & 14 & 10 & 4 & 0 & 0 & 0 & 0 \\
\hline
\end{tabular}

$\beta$-PL Sendai virus ( $2 \mathrm{mg}$ in $1 \mathrm{ml}$ of the appropriate buffer) was digested with proteolytic enzymes as follows: $a$, no enzyme; $b$ trypsin ( $8 \mu 1$, $5 \mathrm{mg} \mathrm{ml}^{-1}$; TPCK-treated, Worthington) for $1 \mathrm{~h}$ at $37^{\circ} \mathrm{C}$ in $0.5 \%$ ammonium bicarbonate buffer, $p \mathrm{H} 8 . c$, V8 protease from Staphylococcus aureus $\left(50 \mu \mathrm{l}, 1 \mathrm{mg} \mathrm{ml}^{-1}\right.$; Miles) for $18 \mathrm{~h}$ at $37^{\circ} \mathrm{C}$ in $50 \mathrm{mM}$ ammonium bicarbonate buffer, $p \mathrm{H} 8 ; d$, pronase $\left(8 \mu \mathrm{l}, 5 \mathrm{mg} \mathrm{ml}^{-1} ; \mathrm{Calbiochem}^{\circ}\right.$ for $4 \mathrm{~h}$ at $37^{\circ} \mathrm{C}$ in PBS buffer. The capacity of the virus preparations to induce target cell formation was measured in the cytotoxic assay described in Fig. 1. Haemagglutinin, neuraminidase and haemolytic activities were measured as before ${ }^{5}$. For cell fusion measurements replicate newly confluent cultures of $\mathrm{Hep} 2$ cells in $30 \mathrm{mM}$ plastic Petri dishes were inoculated with $0.1 \mathrm{ml}$ of the virus preparation in $\mathrm{PBS}$ containing $\mathrm{Mg}^{2+}$ and $\mathrm{Ca}^{2+}$, or were mock infected. Following virus adsorbtion for $1 \mathrm{~h}$ at $37^{\circ} \mathrm{C}$ the cultures were overlaid with $2.0 \mathrm{ml}$ of Dulbecco's reinforced Eagles medium containing $10 \%$ fetal calf serum. After incubation for $2 \mathrm{~h}$ at $37^{\circ} \mathrm{C}$ in an atmosphere not enriched with $\mathrm{CO}_{2}$ the number of nuclei per 100 cells were counted for several fields on each dish.

determine which glycoprotein is primarily responsible for target formation, because both $\mathrm{HA}$ and $\mathrm{F}$ activities are required for virus-cell fusion. Further studies using a temperature-sensitive $\mathrm{HANA}^{-}$mutant of Sendai virus are in progress to elucidate this question.

Insertion of the viral glycoprotein(s) into the cell membrane may be required to facilitate interaction with the $\mathrm{MHC}$ gene products. However, at this stage there is no evidence to discriminate between the hypotheses of one or two T-cell receptor mechanisms, that is, whether the viral glycoprotein(s) interact directly with the MHC antigens or whether they act as independent antigens for $\mathrm{T}$-cell recognition.

U.K. was supported by a grant from the Deutsche Forschungsgemeinschaft.

\section{Protein Chemistry Laboratory,}

Imperial Cancer Research Fund,

\section{MARY-JANE GETHING}

Tumour Immunology Unit,

\section{ULRICH KOSZINOWSKI*}

University College,

London WC1, UK

\section{MICHAEL WATERFIELD}

Protein Chemistry Laboratory,

Imperial Cancer Research Fund,

Lincoln's Inn Fields,

London WC2, UK

Received 7 April; accepted 3 July 1978

* Present address: Institut für Immunologie und Genetics, Deutches Krebs Forschungscentrum, Heidelberg, FRG,

1. Zinkernagel, R. M. \& Doherty, P. C. Nature 248, 701-702 (1974).

2. Munro, A. \& Bright. S. Nature 264, 145-152 (1976)

3. Schrader, J. W. \& Edelman, G. M. J. exp Med. 145, 523-539 (1977).

4. Koszinowski, U. \& Thomssen, R. Eur. J. Immun. 5, 245-251 (1975)

5. Koszinowski, U., Gething, M. J. \& Waterfield, M. Nature 267, 160-163 (1977)

6. Sugamura, K., Shimizu, K., Zarling, D. A. \& Bach, F. G. Nature 270, 251-253 (1977).

7. Tozawa, H., Watanabe, M. \& Ishida, N. Virology 55, 242-253 (1973).

7. Tozawa, H., Watanabe, M. \& Ishida, N. Virology 55, 242-25,

8. Homma, M. \& Ouchi, M. J. Virol. 12, 1457-1465 (1973).

9. Scheid, A. \& Choppin, P. W. Virology \$7, 475-490 (1974).

. Hosaka, Y., and Shimizu, K. in Virus Infection and the Cell Su
Nicolson, G. E.) 129-155 (North-Holland, Amsterdam, 1977).

\section{Mapping of $\mathrm{H}-2$ genes associated with $T$ cell-mediated cytotoxic responses to SV40- tumour-associated specific antigens}

T CELL-MEDIATED cytotoxic responses to cells carrying viral antigens $^{1}$, haptens ${ }^{2}$ and male $\mathrm{H}-\mathrm{Y}$ antigen ${ }^{3}$, as well as minor histocompatibility antigens ${ }^{4}$ are known to be associated with either the $K$ or $D$ region of the murine major histocompatibility complex $(H-2)$. Similarly, T cell-mediated cytolysis of SV40-transformed cells expressing tumour-associated specific antigens (TASA) is restricted to syngeneic target cells ${ }^{5-8}$. Although good cytotoxic responses to SV40-transformed cells can be found in mice of $H-2^{b}$ haplotype after primary in vivo immunisation ${ }^{5}$, the response of mice of other $\mathrm{H}-2$ haplotypes is quite poor (unpublished observations), but can be readily demonstrated after in vitro ${ }^{6-8}$ mixed cell cultures. We demonstrate here primary cytotoxic responses to SV40-TASA in various inbred mouse strains using an immunisation protocol previously applied to the primary in vivo induction of haptenspecific $^{9}$ and virus-specific cytotoxic $\mathrm{T}$ lymphocytes (CTL) ${ }^{10}$. Moreover, the availability of appropriate congeneic recombinant mice as responders and SV40-transformed cells from these mouse strains as target cells, has enabled us to map the anti-SV40-TASA response within the $H-2$ complex. The data establish that the response is restricted to $H-2 K$ or $H-2 D$, and indicate the existence of a possible $I r$ gene influence on the T-cell response to SV40-TASA associated with $H-2 D^{d}$.

B10 and BALB/c mice were immunised with SV40 (legend to Fig. 1). The kinetics of the CTL generation were studied by varying the time of in vivo immunisation (Fig. 1) as well as the in vitro culture period (Fig. 2). Antigenic specificity of the CTL was investigated using SV40- and adenovirus 5-transformed cells as targets for the ${ }^{51} \mathrm{Cr}$ release assay. Maximum cytotoxic activity was obtained in $\mathrm{B} 10$ and $\mathrm{BALB} / \mathrm{c}$ mice $7 \mathrm{~d}$ after in vivo immunisation followed by a further $3 \mathrm{~d}$ in vitro culture period (Figs 1,2 ). In accordance with earlier results ${ }^{5}$, CTL could be demonstrated in $\mathrm{B} 10$ mice when tested directly $7 \mathrm{~d}$ after immunisation, whereas at that time, BALB/c lymphocytes did not mediate specific lysis of the same SV40-transformed $(\mathrm{BALB} / \mathrm{c} \times \mathrm{C57BL} / 6) \mathrm{F}_{1}$ target cells (Fig. 2, day 0 in vitro). However, after a $3 \mathrm{~d}$ in vitro incubation without addition of 